\title{
The role of the automobile industry in the economy of developed countries
}

\begin{abstract}
The article is devoted to the analysis of the role of the automobile industry in the economy of developed countries. The work reflects the extremely high role of the automotive industry in GDP growth and employment generation, the ability of the automotive industry to form a taxable base and revenues of the state budget, As well as the role of the automobile industry in the development of auxiliary industries and the stimulation of scientific and technological progress.
\end{abstract}

Keywords: economy, automobile industry, GDP, development, employment
Volume 4 Issue 3 - 2018

\author{
Behzad Saberi \\ Chair of national economy of the PFUR, Peoples' Friendship \\ University of Russia, Russia
}

\begin{abstract}
Correspondence: Behzad Saberi, Chair of national economy of the PFUR, Peoples' Friendship University of Russia, Russia, Tel +79255209040, Email behzad.saberi@mail.ru
\end{abstract}

Received: April 19, 2018 | Published: May 17, 2018

\section{Introduction}

The automobile industry is a capital-intensive and knowledgeintensive industry, plays an important role in the country's socio-economic development. Currently, the industry is booming, involving an increasing number of countries in the production of cars, while the alignment of forces in the automotive market is constantly changing. The role of the automobile industry in the development of the modern economy and the prospects for its development is determined by the place of motor transport in the infrastructure of the national economy. The article talks about the historical development of the automobile industry in developed countries, analyzes the current situation, makes forecasts and highlights the main trends in their automotive industry. Currently, the development of the country's economy is difficult to imagine without the development of the automobile industry. According to the world association of car manufacturers "OICA" in 2017, 73.4 million cars and 23.84 million trucks were produced in the world. ${ }^{1}$ According to international estimates, the average annual turnover of the world automobile industry is more than 2.75 trillion. Euro, ${ }^{2}$ which corresponds to $3.65 \%$ of world GDP. In the automotive industry over the last ten years (2007-2017) there was a $25 \%$ increase in production. Cars are one of the world's largest export products, surpassing oil revenues, for example, world car exports by country ${ }^{3}$ in 2016 estimated at 698.2 billion dollars. USA. The industry is also a major innovator, investing more than 84 billion euros in research, development and production. So among the 2500 leading companies in the investment in R\&D, three major sectors dominate: pharmaceuticals and biotechnology, production of process equipment, and the automotive industry. For example, only the volume of investment in R\&D corporation $\mathrm{VW} \mathrm{AG}^{4}$ in 2014 has become about 13 billion euros, and two years later in 2016 about 13.2 billion US dollars. It is worth noting that tax revenue from car manufacturers in 26 industrialized countries is more than 430 billion euros per year.

\section{Discussion}

The auto industry consumes steel, iron, aluminum, plastic, glass, carpeting, textiles, computer chips, rubber and much more. According to statistics, about half of the world consumption of oil, rubber, about 1/4 of the glass output, and $1 / 6$ of the steel output is accounted for by the automobile industry. The industry is the second after aircraft construction in terms of the volume of consumed products of other industries. In the economy of developed countries, growth in the automotive industry by $1 \%$ causes a GDP growth of $1.5 \%$. Indirect impact of the automotive industry on GDP is strengthened through related industries, provided by orders from the automotive industry. The automotive industry in the developed countries is the leading branch of machine building. There is not a single large economy that does not have a large automotive industry on its territory. Therefore, the share of the automobile industry in the GDP of developed countries ranges from 5 to $10 \%$. The share of this branch in the machine-building production of Germany is $14 \%$, Japan- $12 \%$, South Korea-10\%. One dollar invested in the automotive industry increases the gross domestic product by $\$ 3$ (average multiplier). According to this indicator, the automotive industry has no equal among other sectors. According to various forecasts ${ }^{5}$ by 2030 , the gross revenue of the auto industry is significantly increasing, and the industry will bring an additional income of 1.5 trillion. (An increase in income of $30 \%$ ). While the revenue from traditional car sales, and after-sales maintenance, and sales of spare parts will be about 5.2 trillion USD. In 2015, this figure was only 3.5 trillion USD. Together, these revenues can accelerate the annual growth of the automotive industry to $4.4 \%$. The aggregate performance of the global automotive industry allowed the International Organization of Automobile Manufacturers "OICA" to equate it to the world's sixth largest economy. Modern automakers and experts of the automotive market forecast that the annual growth rates of the world automotive market will be about $3.6 \%$, which roughly corresponds to the dynamics of world GDP. ${ }^{6}$ Thus, the automotive industry represents one of the key branches of the economy, providing development of other industries and the country as a whole. The successful work of the auto-building complex depends on the well-being and fate of millions of inhabitants, and also to a large extent the country's defense capability. The automotive industry in countries such as the US, Japan, Germany, and South Korea is a vivid example of the formation of a global "super-industry." Table 1 shows the ratio of macroeconomic parameters of these countries and the development of the automotive industry.

The data in Table 1 show that the more developed the automobile industry in the country, the higher the share of GDP of this country in world production. It is important to note that the level of development of the country's economy is characterized, in particular, by the size and structure of exports and imports. In the industrial structure of industry in the US, Germany, Japan, South Korea, the share of engineering, is including automotive, ranges from 25 to $40 \%$. In developing countries, this figure is less than $10 \%$. The more effective the economy, the greater it's share in world exports, and the export structure has more high-tech products and less raw materials. In terms of exports of goods per capita (Table 1), these countries are among the top 10 exporting countries. The structure of exports of these countries includes cars and aircraft, machinery and equipment, computers and other electronics, sophisticated household appliances, etc. However, most of the export from these countries is made up of cars, vehicles, parts and accessories. It is the volume of machinery and equipment export in these countries that is considered to be the most important indicator of the level of technological development of the state, and the trends in this sector change characterize the effectiveness of state management. The automotive industry has a developed and complex infrastructure located all over the world. Today, it is on the verge of radical changes in the structure of exports and all foreign economic activity. ${ }^{7-11}$ 
Table 1 The ratio of macroeconomic parameters and the share of automotive parameters of the leading countries in 2017

\begin{tabular}{|c|c|c|c|c|c|}
\hline \multicolumn{2}{|l|}{ Parameters } & USA & Japan & Germany & $\begin{array}{l}\text { South } \\
\text { Korea }\end{array}$ \\
\hline \multicolumn{2}{|l|}{ Share of GDP in world production (\%) } & 24.42 & 5.6 & 4.57 & 1.85 \\
\hline \multicolumn{2}{|c|}{ The share of the automotive industry in world production (\%) } & 12.3 & 10 & 6 & 4,9 \\
\hline \multicolumn{2}{|l|}{ The share of the automotive industry in GDP (\%) } & 12 & 12 & 14 & 10 \\
\hline \multicolumn{2}{|l|}{ The country's share in world exports of goods $(\%)$} & 9,1 & 3,8 & 8,1 & 3,2 \\
\hline \multicolumn{2}{|l|}{ Commodity exports (billions of dollars) } & 1504,9 & 624,9 & 1329,5 & 526,8 \\
\hline \multicolumn{2}{|c|}{ The volume of exports of machinery and transport equipment (billion dollars) } & 664,9 & 400,6 & 729,6 & 315,1 \\
\hline \multicolumn{2}{|l|}{ The volume of export of cars (billion dollars) } & 53,8 & 91,9 & 151,9 & 37,5 \\
\hline \multirow[t]{2}{*}{ Number of employment in the automotive industry: } & Direct (th.) & 870 & 803 & 807 & 320 \\
\hline & Indirect (million) & 7,2 & 5,5 & 1,8 & 1,83 \\
\hline \multicolumn{2}{|l|}{ Share of industry in GDP (\%) } & 19,9 & 26,6 & 32,5 & 39,7 \\
\hline
\end{tabular}

\section{Conclusion}

In the modern age-the development of the economy of any country cannot be imagined without the development of the automobile industry. In recent years, the global share of the automotive industry in the GDP structure is increasing, and the growth dynamics will create new jobs and increase the average wage. The automotive industry contributes to the expansion of the taxable base and revenues of the state budget, develops auxiliary branches, influences scientific and technical progress, testifies to the level of solvent demand and the standard of living of the population of the country and much more. Thus, the effective functioning and development of the automotive industry is important not only economic, but also social significance for any country.

\section{Acknowledgements}

None.

\section{Conflict of interest}

The author declares there is no conflict of interest.

\section{References}

1. International organization of automobile manufacturers. OICA. 2017.

2. Aleksandrov IA. The basic tendencies of development of the world motor industry in modern conditions. International scientific bulletin. $2013 ; 2: 327-340$
3. Daniel Workman. Car Exports by Country. WTEx; 2018.

4. The Economics of Industrial Research \& Innovation (IRI). JRC; 2017.

5. Evaluation of the prospects of the world auto industry. Science abroad. 2016;50.

6. Starkova NO, Kandalov. Theoretical aspects and main trends of the modern automobile market. Siberian Economic Herald. 2016;3:7789.

7. Akimkina DA. Problems of the development strategy of the automotive industry and ways to solve them. Financial analytics: problems and solutions. 2014;7:44-54.

8. Kalabekov IG. Russian reforms in figures and facts - Moscow. $2^{\text {nd }}$ ed. revised and supplemented. Publishing houses RUSAKI; 897C.

9. Ovchinnikova AV, Karpova MA. Application of the theory of industrial markets to the study of modern trends in the development of the automotive industry. Bulletin of the Udmurt University; Series Economics and Law. 2015;2-3:55-62.

10. Shablinsky I, Danilov E. Automotive industry, production, sales, consumer disputes. Legal aspect. M Alpina Publisher; 2009: 152 p.

11. Companies shifting more R\&D spending away from physical products to software and services: Global Innovation 1000 Study. PwC; 2016. 